\title{
Governance and ownership in Malaysia: their impacts on corporate performance
}

\author{
Nazli Anum Mohd Ghazali \\ Department of Accounting, International Islamic University Malaysia, \\ Kuala Lumpur, Malaysia
}

\begin{abstract}
Purpose - The aim of this paper is to examine the relative influence of regulatory enhancements relating to corporate governance and attributes of business traits on performance of Malaysian listed companies.

Design/methodology/approach - Regression analysis was performed on all 742 non-financial main board companies listed on Bursa Malaysia using data from 2013 annual reports.

Findings - The results show that the number of board meetings held during the year, role separation and board size have a significant impact on corporate performance. By contrast, independent directors, government ownership and director ownership do not influence corporate performance.

Research limitations/implications - The study investigated non-financial companies for the financial year 2013. Hence, the results may not apply to financial companies and other years. Future research can perhaps include all types of listed companies and carry out a longitudinal study to gain more comprehensive results and understanding on the relationship between corporate governance and corporate performance. Additionally, future research could also consider employing a different methodology to further unveil factors influencing corporate performance.

Practical implications - The above findings provide new evidence of the effectiveness of the Malaysian Code on Corporate Governance in improving company performance. The significance of board meetings, role separation and board size shows the importance of internal governance in shaping company processes and hence performance.

Originality/value - The result suggests that although the Malaysian Code on Corporate Governance follows the corporate governance code of developed countries, the applicability of the recommendations to a developing country is evidenced. Companies in Malaysia are predominantly government-owned or closely held, but it appears that role separation matters even in these types of companies in achieving better performance.
\end{abstract}

Keywords Corporate governance, Corporate performance, Board size, Board meetings, Role duality, Government ownership, Director ownership

Paper type Research paper

\section{Introduction}

The governance landscape in the Malaysian business environment has gone through a series of improvements since the introduction of the Malaysian Code of Corporate Governance (MCCG) in 2000. The MCCG, which was the result of consultations between various parties in response to the need to restore investors' confidence in the Malaysian market due to the economic collapse brought about by the 1997/98 financial crisis, was revised in 2007 and 2012 to further clarify the roles and responsibilities of the board of directors. Central to the MCCG is the importance of enhancing corporate transparency and accountability.

(C) Nazli Anum Mohd Ghazali. Published in Asian Journal of Accounting Research. Published by Emerald Publishing Limited. This article is published under the Creative Commons Attribution (CC BY 4.0) licence. Anyone may reproduce, distribute, translate and create derivative works of this article (for both commercial and non-commercial purposes), subject to full attribution to the original publication and authors. The full terms of this licence may be seen at http://creativecommons.org/licences/by/4.0/legalcode.

The author gratefully acknowledges the financial support from the Ministry of Higher Education, Malaysia (FRGS13-057-0298) in carrying out this research project. The author is also appreciative of the constructive comments and suggestions given by the editor and anonymous reviewers on the paper.
Governance and ownership in Malaysia

Received 21 March 2020 Revised 12 May 2020

11 June 2020

21 July 2020

Accepted 28 July 2020

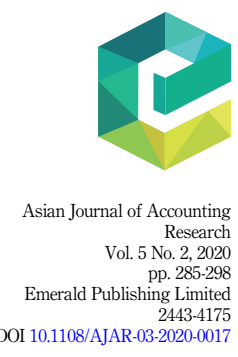


AJAR

5,2

286

The original MCCG introduced in 2000 and following much of the UK Corporate Governance Code sets out principles and guidelines to assist companies in designing the corporate governance approach. Among the recommendations of the MCCG (2000) were clear separation of roles between the chairman and the chief executive officer (CEO) and independent directors making up at least one-third of the board membership. The revised MCCG (2007) provides the eligibility criteria for the appointment of directors, audit committees, frequency of meetings and the need for continuous training. The MCCG (2007) also requires all public listed companies to have an internal audit function with the head reporting directly to the audit committee. The MCCG (2012) includes in its principles the need for having formalized ethical standards through code of conduct and company strategies to promote sustainability. The tenure of an independent director is also specified in addition to requirement of annual assessment of the independent directors. The continuous improvements to the MCCG show the seriousness of the Malaysian government in guiding companies towards effective governance structure and efficient monitoring by corporate boards. However, whether these revisions and improvements had led to better corporate performance remains inconclusive as prior studies reported mixed results.

Additionally, as is the case with many emerging economies, the Malaysian business environment is dominated by family-controlled and government-owned companies. Claessens et al. (2000) found extensive family control in more than one-half of the East Asian corporations, while state control is significant in Indonesia, Korea, Malaysia, Singapore and Thailand. These types of ownership structure are in contrast to the widely held companies that commonly exist in most developed countries (La Porta et al., 1999). Prior studies have also reported that family firms are generally secretive in nature as evidenced by a lower extent of disclosure (Haniffa and Cooke, 2002; Ho and Wong, 2001; Mohd Ghazali and Weetman, 2006) as they may not be relying to any considerable extent on external financing. The difference in types of ownership structure raises the question of the applicability of governance guidelines designed for developed countries to emerging economies.

A study by Mardnly et al. (2018) on Syrian listed companies reported significant association between foreign ownership and firm performance, while concentrated managerial ownership and corporate governance had no impact on firm performance. The authors attributed the non-significance findings on corporate governance to lax oversight by the regulatory authority and political situation in Syria due to the war. Meanwhile Kao et al. (2019) who studied the effects of corporate governance reform in newly industrialised country Taiwan found corporate governance mechanisms have a significant influence on firm performance. These findings imply that a country's political environment or stability and economic development may have some influence on the effectiveness of regulatory actions and business traits.

In the Malaysian context, previous studies by Ahmed Haji (2014) and Ahmed Haji and Mubaraq (2015) examined the influence of corporate governance pre- and post-MCCG (2007). These studies reported the significance of board size and board meetings in influencing corporate performance post MCCG (2007). The authors partly attributed the findings to the possible impact of the global financial crisis in 2007/2008 as it was also observed that corporate performance worsened from 2006 to 2009 (Ahmed Haji, 2014). The present study extends prior research by investigating all non-financial companies in a crisis-free environment and following the third version of the MCCG, i.e. MCCG (2012) to provide a more comprehensive analysis of the impact of both corporate governance and ownership structure on firm performance.

The aim of this paper is to examine the relative influence of regulatory enhancements relating to corporate governance and attributes of business traits on performance of Malaysian listed companies. The paper is based on the expectation that given the continuous enhancements made to the MCCG beginning with the issuance in 2000 and revisions in 2007 
and 2012, companies would be more sensitized to apply the essence or spirit of the guidelines rather than adopting a box-ticking approach. This in turn should lead to a better corporate performance. On the other hand, traditional business culture is endemic and may be difficult to change. In this context, the unique ownership structure observed in developing countries including Malaysia may have a lasting effect on corporate performance as the economy in these countries has been described as relationship-based or crony capitalism (Fraser et al., 2006; Gomez and Jomo, 2002; Johnson and Mitton, 2003). The contribution of this paper is by way of determining whether the initiatives taken by the Malaysian government, i.e. regulatory factors on corporate governance, can outweigh the long traditional influence of business traits, i.e. ownership structure, on corporate performance.

The research questions $(\mathrm{RQ})$ of this study are as follows:

$R Q 1$. Do companies which adopt the recommendations of the MCCG perform better than others?

$R Q 2$. Does ownership structure have an impact on corporate performance?

The results show that the number of board meetings held during the year, role separation and board size have a significant impact on corporate performance, while company size as a control variable is marginally significant. In contrast, independent directors, government ownership and director ownership do not influence corporate performance. These findings suggest that companies with fewer board meetings during the year, different individuals holding the chairmanship and CEO post and larger board size are associated with higher corporate performance. It appears that regulatory efforts to enhance corporate governance are proving fruitful in terms of promoting greater corporate accountability and hence better performance. The results also imply that over time the influence of traditional traits may diminish as is evident in the non-significance of government ownership and director ownership in the present study.

The remainder of the paper is organized as follows: Section 2 develops the hypotheses based on the literature review and theoretical expectations. Section 3 details the research method explaining the sample selection process and regression model. This is followed by the findings and analysis in Section 4. Conclusion, limitations and suggestions for future research are provided in the last section.

\section{Literature review and hypotheses development}

The focus of this study is the impact of corporate governance and ownership structure on corporate performance. The ensuing sub-sections discuss and develop hypotheses relating to these variables.

\subsection{Corporate governance}

Corporate governance is represented by board size, independent non-executive directors, role duality and board meetings. The selection of variables in this category is made with reference to MCCG (2012).

2.1.1 Board size. Resource dependence theory suggests that the different skills, knowledge and expertise brought into board discussions will help enhance corporate performance. This implies that boards which constitute more members will be associated with better corporate performance. Empirical studies which found support for a significant positive relationship between board size and corporate performance include Al Farooque et al. (2020), Al-Matari (2020), Bhatt and Bhattacharya (2015), Jackling and Johl (2009), Mishra and Kapil (2018) and Ofoeda (2017).

By contrast, Jensen (1993) contends that a larger board size is more prone to disagreement and confrontation which may be difficult to resolve. This argument suggests that more
Governance and ownership in Malaysia

\section{(1)}


AJAR 5,2

members on the board with opposing views may be associated with inferior corporate performance. A number of prior studies provide support for this contention that board size has a negative relationship with corporate performance. Included in these studies are Afrifa and Tauringana (2015), Kao et al. (2019) and Mak and Kusnadi (2005), while Darko et al. (2016) and Shao (2019) did not observe a significant relationship.

Principle 2 on strengthening composition in MCCG (2012) does not specify the number of board members a company should appoint. Earlier studies on board size and corporate performance in Malaysia did not document a significant relationship between the two variables (Ahmed Haji, 2014; Mohd Ghazali, 2010, 2014). However, these studies investigated a sample before 2012 and did not include all listed companies in their analyses. A study by Hussain and Hadi (2019) reported board size to be significant and negatively associated with financial performance of small and medium companies in the Malaysian construction industry. However, no significant relationship was found in listed companies. As prior studies documented mixed results on the relationship between board size and corporate performance, a non-directional hypothesis is proposed:

H1. There is a significant relationship between board size and corporate performance.

2.1.2 Independent directors. The potential for agency conflicts is higher in widely held companies due to divergence of interests among contracting parties (Jensen and Meckling, 1976). Agency conflicts in corporations in developing countries are expected between ownermanagers and outside shareholders. To reduce these conflicts, independent directors can be appointed to look after the interests of outside shareholders and limit managerial opportunism (Fama and Jensen, 1983).

The MCCG recommends that independent directors make up one-third of the board, and the Bursa Malaysia requires all listed companies to comply with this provision. Empirical findings on the relationship between independent directors and corporate performance are inconclusive. A number of studies found no significant relationship between independent directors and corporate performance (Afrifa and Tauringana, 2015; Bhatt and Bhattacharya, 2015; Chen et al., 2005; Shao, 2019). This may not come as a surprise as there have been questions on the "independency" of these independent directors (Meng, 2009; Mohd Ghazali and Weetman, 2006).

Nonetheless, there are studies documenting the significance of independent directors in enhancing corporate performance (A1 Farooque et al., 2020; Jackling and Johl, 2009; Kao et al., 2019). Darko et al. (2016) and Nguyen et al. (2017) on the other hand, observed a significant negative association between independent directors and corporate performance.

In the Malaysian context, three prior studies using data pre- MCCG (2012) did not find a significant relationship between independent directors and corporate performance (Ahmed Haji, 2014; Leng, 2004; Mohd Ghazali, 2010). However, these studies were examining data pre2012 and did not include all listed companies in the analysis. As the most recent MCCG was revised in 2012 and independent directors are one of the recommendations of the MCCG, it is expected that since the MCCG was introduced more than ten years ago and revised twice, companies are more aware of the essence of the code. In turn, independent directors should also be efficient in discharging their duties, thereby contributing to better corporate performance. The following hypothesis is proposed:

H2. There is a significant positive relationship between the proportion of independent directors and corporate performance.

2.1.3 Role duality. The argument for separating the roles of chairman and CEO (i.e. different individuals holding these positions) is based on the need to balance power and authority. If these two positions are held by the same individual, a concentration of power may exist in the company and consequently the board may not be able to function efficiently. A chairman 
should oversee the performance of the directors, while the CEO is involved in the daily operations of the business. Clear divisions of responsibilities between the chairman and the CEO promote transparency and accountability, thereby steering companies towards enhanced performance.

Empirical evidence appears to suggest that combining the roles results in worse performance (Al Farooque et al., 2020; Chen et al., 2005; Haniffa and Hudaib, 2006; Kao et al., 2019; Shao, 2019). Mishra and Kapil (2018) found that separating the roles resulted in better corporate performance in Sri Lanka. By contrast, Jackling and Johl (2009), Ofoeda (2017) and Puni and Anlesinya (2020) observed no significant relationship between combined role and corporate performance. In Malaysia, Rahman and Haniffa (2005) reported a negative relationship, while Leng and Abu Mansor (2005) found a positive relationship between role duality and corporate performance. As the MCCG specifically lists role separation as one of its recommendations, companies which follow this recommendation are expected to perform better than others. The following hypothesis is proposed:

H3. There is a significant positive relationship between role separation and corporate performance.

2.1.4 Board meetings. According to Vafeas (1999), companies should balance the cost and benefits associated with board meetings to ensure a positive impact on corporate performance. Vafeas (1999) further suggests that if board activity is a proxy for active monitoring by the board of directors, as insiders' ownership increases less supervision by the board is required. A board that meets frequently can be an indication of problems in the company that require immediate or continuous monitoring and decisions. Empirical evidence supporting this view includes Lopez-Quesada et al. (2018) and Ofoeda (2017), where a negative association was observed between number of board meetings and corporate performance.

Khanchei (2007), on the other hand, opines that a board that meets frequently implies a well-functioning and active board. Board meetings have been found to have a significant positive impact on firm performance (Al Farooque et al., 2020; Brick and Chidambaran, 2010; Mishra and Kapil, 2018; Puni and Anlesinya, 2020). This finding suggests that more frequent board monitoring allows strategic decisions to be made at more regular intervals. Elsewhere, no significant relationship was found between number of board meetings and corporate performance (Bhatt and Bhattacharya, 2015; Jackling and Johl, 2009).

In Malaysia, Ahmed Haji (2014) and Ahmed Haji and Mubaraq (2015) reported significant negative association between board meeting and market performance for the post MCCG (2007) data. The pre-MCCG (2007) data however did not show significant association between board meetings and firm performance. As prior studies documented mixed results on the relationship between board meetings and corporate performance, a non-directional hypothesis is proposed:

H4. There is a significant relationship between board meetings and corporate performance.

\subsection{Ownership structure}

Ownership structure is represented by government ownership and director ownership, the two significant features of business environment in Malaysia. Government-controlled companies may be expected to perform better than others due to public pressure and high public accountability in these companies. Director ownership is akin to owner-managed companies and has incentives to perform well to avoid hostile takeover and outside participation.

2.2.1 Government ownership. A government-controlled company may have additional pressure to generate high profits to legitimize its existence. It may also be expected that 
because the level of public accountability in this type of company is high, governmentcontrolled companies would work harder to meet the nation's expectations. Fauzi and Musallam (2015) found support for a significant positive association between government ownership and corporate performance. Ang and Ding (2006) also reported that governmentlinked companies in Singapore had higher market valuation than other companies.

By contrast, Alipour (2013) documented a negative association between government ownership and corporate performance, attributing the finding to the government's preference toward social and political goals as opposed to shareholders' wealth. Shen and Lin (2009) and Zeitun and Tian (2007) also observed a significant negative relationship between state ownership and corporate performance. Elsewhere, state ownership was not found to be influencing corporate performance (Darko et al., 2016).

Prior studies on Malaysia found a significant positive relationship between government ownership and corporate performance (Mohd Ghazali, 2010, 2014), implying constant monitoring by the government in this type of companies aided in discharging public accountability and hence legitimized their existence. This type of ownership structure is expected to continue to prevail in Malaysia. However, its impact on corporate performance remains to be seen given the heightened focus on corporate governance. The following hypothesis is proposed:

H5. There is a significant positive relationship between government ownership and corporate performance.

2.2.2 Director ownership. Ownership of shares by directors may help reduce agency conflicts because owner-managers will have more incentives to maximise job performance (Jensen and Meckling, 1976). A director who owns a large number of shares will be motivated to exert greater efforts to maximize performance as he would reap the outcome of his actions. On the other hand, entrenched management may engage in expropriation (Morck et al., 1988) leading to worse corporate performance. Fauzi and Musallam (2015) found evidence that board ownership destroys company performance. A study by Shao (2019) also showed significant negative relationship between managerial ownership and firm performance in Chinese listed firms.

Empirical evidence supporting agency prediction includes Agrawal and Knoeber (1996), Al Farooque et al. (2020) and Daily and Dalton (2004). These studies reported a significant positive association between director ownership and corporate performance. Additionally, Lappalainen and Niskanen (2012) documented that companies with high managerial ownership exhibited higher profitability. Alabdullah (2018) also observed a significant positive relationship between managerial ownership and financial performance in Jordanian listed firms.

Other studies including Ahmed Haji (2014), Himmelberg et al. (1999), Mak and Kusnadi (2005) and Mohd Ghazali (2014) observed no significant relationship between director ownership and corporate performance. The revised MCCG (2012) emphasizes further the role of the board in directing their efforts and resources towards the best interest of the company. This responsibility coupled with share ownership should provide the impetus for directors to strive harder for sustainable and enhanced corporate performance. The following hypothesis is proposed:

H6. There is a significant positive relationship between director ownership and corporate performance.

\subsection{Control variable}

Following the practice of prior studies, company size is included as a control variable. It is expected that larger companies are more profitable due to greater diversification and hence 
economies of scale and ability to obtain cheaper financing. Although previous studies had documented the non-significance of company size (Alabdullah, 2018; Al-Matari, 2020), a number of prior studies showed evidence of company size influencing corporate performance with larger companies being more profitable (Ahmed Haji, 2014; Ahmed Haji and Mubaraq, 2015; Al Farooque et al., 2020; Mardnly et al., 2018; Ofoeda, 2017).

\section{Research method}

\subsection{Sample selection}

Pursuant to the introduction of the MCCG in 2000 and subsequent revision in 2007, the MCCG (2012) was issued by the Securities Commission Malaysia in March 2012 and effective immediately. Considering that companies may take some time to familiarize with this new version of the MCCG (2012), all non-financial listed companies with financial year end 31 December 2013 were selected for analysis in the present study. As at 31 December 2013, the total number of companies on the main market of Bursa Malaysia was 814 [1]. Table 1 below summarizes the selection process which results in 742 sample companies. The annual reports of these companies were then downloaded from the Bursa Malaysia website.

To determine the relationship between corporate governance attributes and traditional traits of ownership structure, a multiple regression analysis was performed.

The regression model is as follows:

$$
\begin{aligned}
\mathrm{ROE}= & \beta_{0}+\beta_{1} \mathrm{BODSZ}+\beta_{2} \mathrm{IND}+\beta_{3} \mathrm{DUAL}+\beta_{4} \mathrm{BMEET}+\beta_{5} \mathrm{GOVOWN}+\beta_{6} \mathrm{DIROWN} \\
& +\beta_{7} \mathrm{COSZ}+\varepsilon
\end{aligned}
$$

Table 2 shows operationalisation of the variables included in the analysis.

Statistical analysis on data in this study was run using the Statistical Package for the Social Sciences (SPSS) software version 20.

\section{Findings and analysis}

The association between the independent variables was assessed using correlation analysis.

The correlation analysis in Table 3 shows that the independent variables are not highly correlated with one another. Collinearity cut-off has been suggested as 0.7 (Tabachnick and Fidell, 2001, p. 84); others such as Gujarati (2003) have suggested a higher cut-off value of 0.8. The present study takes 0.7 as the cut-off value for collinearity, to minimise misinterpretation of the statistical results.

The highest correlation is -0.460 which is between board size and independent directors. The negative association implies that companies with larger boards have a smaller proportion of independent directors. Government ownership has positive association with company size $(r=0.377)$, suggesting that government-controlled companies are generally large in size. Board meetings also have a positive association with company size $(r=0.286)$

Bursa Malaysia as at 31 December 2013

Companies listed on main market

Table 1. 


\begin{tabular}{|c|c|c|c|}
\hline \multirow{2}{*}{$\begin{array}{l}\text { AJAR } \\
5,2\end{array}$} & Variable & Definition & Measurement \\
\hline & $\begin{array}{l}\text { Dependent } \\
\text { ROE } \\
\beta_{0} \ldots \beta_{7}\end{array}$ & $\begin{array}{l}\text { zbles } \\
\text { Corporate performance } \\
\text { Regression coefficients }\end{array}$ & Profit after tax/Shareholders' funds \\
\hline 292 & $\begin{array}{l}\text { Independen } \\
\text { BODSZ } \\
\text { IND }\end{array}$ & $\begin{array}{l}\text { iables } \\
\text { Board size } \\
\text { Percentage of independent }\end{array}$ & $\begin{array}{l}\text { Number of board of directors } \\
\text { Number of independent directors/Total number of }\end{array}$ \\
\hline $\begin{array}{l}\text { Table } 2 . \\
\text { Variables included in } \\
\text { the analysis }\end{array}$ & $\begin{array}{l}\text { DUAL } \\
\text { BMEET } \\
\text { GOVOWN } \\
\text { DIROWN } \\
\text { COSZ } \\
\varepsilon\end{array}$ & $\begin{array}{l}\text { directors } \\
\text { Role duality } \\
\text { Board meetings } \\
\text { Government ownership } \\
\text { Director ownership } \\
\text { Company size } \\
\text { Error term }\end{array}$ & $\begin{array}{l}\text { directors } \\
1=\text { chairman is also the CEO/MD } \\
2=\text { chairman is neither the CEO nor } \mathrm{MD} \\
\text { Number of board meetings held during the year } \\
\text { Percentage of shares held by the government } \\
\text { Percentage of shares held by the directors } \\
\text { Market capitalization }\end{array}$ \\
\hline
\end{tabular}

\begin{tabular}{lrcccccc}
\hline & BODSZ & IND & DUAL & BMEET & GOVOWN & DIROWN & COSZ \\
\hline BODSZ & 1 & & & & & & \\
IND & $-0.460^{* *}$ & 1 & & & & & \\
DUAL & $0.151^{* *}$ & -0.042 & 1 & & & & \\
BMEET & $0.206^{* *}$ & 0.006 & 0.045 & 1 & & & \\
GOVOWN & $0.223^{* *}$ & $-0.074^{*}$ & 0.072 & $0.274^{* *}$ & 1 & & \\
DIROWN & $-0.115^{* *}$ & $-0.097^{*}$ & $-0.109^{* *}$ & $-0.212^{* *}$ & $-0.256^{* *}$ & 1 & \\
COSZ & $0.224^{* *}$ & -0.012 & 0.064 & $0.286^{* *}$ & $0.377^{* *}$ & $-0.226^{* *}$ & 1 \\
Note(s): ** correlation is significant at the 0.01 level (2-tailed) & & & & \\
* correlation is significant at the 0.05 level (2-tailed) & & & & \\
\hline
\end{tabular}

Table 3.

Correlation analysis

and government ownership ( $r=0.274)$, implying that larger companies and governmentcontrolled companies held more board meetings during the year.

Government ownership has a negative association with director ownership, which indicates that directors' shareholding is less in government-controlled companies. This is expected as government-controlled companies usually appoint retired civil servants to the board with minimal share ownership. Additionally, director ownership implies ownermanaged companies which are generally smaller in size and have less government participation. The small-size argument is further evidenced in the negative association between director ownership and company size $(r=-0.226)$.

Board size has a positive association with government ownership $(r=0.223)$ and company size $(r=0.224)$, suggesting that government-controlled and larger companies have more members on the board. The larger the board size the more meetings held during the year, as indicated by the positive association between the two variables $(r=0.206)$.

Interestingly, director ownership has a negative association with board meetings $(r=-0.212)$, implying a substitutive relationship between the two variables. It appears that board monitoring in the form of frequency of meetings can be reduced if the company is owner-managed. This finding provides support to Vafeas' (1999) suggestion that if board activity is a proxy for active monitoring, less supervision may be required as insiders' ownership increases.

The regression model with seven independent variables and ROE as its dependent variable as shown in Table 4 resulted in three corporate governance attributes and one 
control variable being statistically significant. Board meeting is statistically significant at the $1 \%$ level, while duality and board size are statistically significant at the $5 \%$ level. The results suggest that companies with fewer number of board meetings, different individuals holding the $\mathrm{CEO}$ and chairman posts and a higher number of board members are more profitable than others. In contrast, independent directors, government ownership and director ownership do not influence corporate performance.

Although much of prior studies showed frequent board meetings led to improved company performance (Al Farooque et al., 2020; Brick and Chidambaran, 2010; Mishra and Kapil, 2018; Puni and Anlesinya, 2020), the finding in the present study suggests otherwise. Board meetings are negatively associated, implying that frequent board meetings are detrimental to corporate performance. This result, which is consistent with studies by Lopez-Quesada et al. (2018) and Ofoeda (2017) indicates that board meetings are costly in financial terms and in signalling that all is not well in the company, necessitating the frequent meetings. The findings in the present study also provide support to earlier studies (Ahmed Haji, 2014; Ahmed Haji and Mubaraq, 2015) which documented significant negative relationship between board meetings and firm performance post implementation in Malaysia.

The result on role separation supports prior studies (Al Farooque et al., 2020; Chen et al., 2005; Haniffa and Hudaib, 2006; Kao et al., 2019; Shao, 2019). The evidence shows that separating the chairman and CEO positions results in better corporate performance, indicating that clear division of authority and responsibility promotes efficiency in the company. This finding also suggests that although the MCCG follows the corporate governance code of developed countries, the recommendations are also relevant to a developing country. Companies in Malaysia are predominantly government-owned or closely held, but it appears that role separation matters even in these types of companies in achieving better performance. Prior studies on Malaysian companies using data pre-MCCG (Leng and Abu Mansor, 2005; Rahman and Haniffa, 2005) produced inconsistent results. Hence, the finding in the present study which analysed all non-financial listed companies post MCCG (2012) is noteworthy in determining the effectiveness of the MCCG (2012) in enhancing corporate performance.

The significance of board size in improving corporate performance is consistent with a number of prior studies (Al Farooque et al., 2020; Al-Matari, 2020; Bhatt and Bhattacharya, 2015; Jackling and Johl, 2009; Mishra and Kapil, 2018; Ofoeda, 2017). In addition, contrary to prior findings on board size in Malaysia (Ahmed Haji, 2014; Mohd Ghazali, 2010, 2014) which did not document the significance of board size, the present study highlights its significance in enhancing corporate performance. This finding suggests that regulatory enhancements on corporate governance may take some time to produce the intended results as prior studies on

\begin{tabular}{lccccc}
\hline$R$ squared & Beta & $t$ value & $\begin{array}{c}4 \% \\
\text { Significance }\end{array}$ & Tolerance & VIF \\
\hline Constant & & -1.928 & 0.054 & & \\
BODSZ & 0.092 & 2.121 & $0.034^{* *}$ & 0.693 & 1.444 \\
IND & 0.065 & 1.557 & 0.120 & 0.756 & 1.323 \\
DUAL & 0.090 & 2.448 & $0.015^{* *}$ & 0.968 & 1.033 \\
BMEET & -0.165 & -4.223 & $0.000^{* * *}$ & 0.853 & 1.172 \\
GOVOWN & 0.042 & 1.031 & 0.303 & 0.792 & 1.263 \\
DIROWN & 0.023 & 0.601 & 0.548 & 0.795 & 1.143 \\
COSZ & 0.069 & 1.710 & $0.088^{*}$ & & 1.258
\end{tabular}

Governance and ownership in Malaysia

293

Note(s): Coefficients are shown as significant at $1 \% * * *, 5 \% * *$ or $10 \% *$ level

Table 4.

Multiple regression results - dependent variable: $R O E$ 
Malaysian companies employing data pre-MCCG (2012) did not find board size to influence 5,2 corporate performance. The results of the present study imply that larger board size allows better exchange of ideas and formulation of strategic policies, thereby driving companies toward better performance.

\section{Conclusions, limitations and suggestions for future research}

The aim of the paper is to determine if the continuous revisions on the corporate governance code succeeded in enhancing corporate performance and whether the traditional traits of ownership structure continue to influence corporate performance. The regression analysis of all non-financial main board companies listed on Bursa Malaysia shows that board meetings, role duality and board size are significant determinants of corporate performance. In contrast, government and director ownership are no longer influencing corporate performance.

The results imply that fewer board meetings are associated with better corporate performance. This may be interpreted as fewer meetings signalling fewer problems in the company and hence a better corporate performance. Separation of roles also appears to facilitate division of accountability and responsibility leading to enhanced corporate performance. The significance of board size suggests that the bigger the board size, the higher the possibility of having members with diverse backgrounds, skills and experience. These qualities when brought into boardroom discussion assisted the board in arriving at optimal decisions.

The above findings provide new evidence of the effectiveness of the MCCG (2012) in improving company performance. Although the MCCG (2012) does not specifically state the recommended number of board meetings and board size, the significance of these attributes together with role duality show the importance of internal governance in shaping company processes and hence performance. Companies should therefore apply the principles prescribed in the MCCG (2012) diligently to ensure optimum output and sustainable performance. The non-significance of the ownership variables indicates they are less important than corporate governance in determining corporate performance. It appears that as businesses grow and with a globalized economy, traditional traits may not have a significant role in ensuring business prosperity.

The results imply that Malaysia should continue focussing on enhancing corporate governance in order to further promote corporate sustainability. Of the four corporate governance variables investigated in this study, only independent directors were found to be insignificant. Although this finding had been observed in previous studies (Ahmed Haji, 2014; Leng, 2004; Mohd Ghazali, 2010), those studies examined data pre-MCCG (2012) and did not include all non-financial listed companies. The present study shows that concerns over the effectiveness of independent directors (Meng, 2009; Mohd Ghazali and Weetman, 2006) are still valid. Even after more than ten years of the issuance of the first version of the MCCG, the impact of the presence of independent directors on corporate performance is unclear. The relevant regulatory authority could perhaps provide guidelines to strengthen and refine the criteria and process of appointing independent directors so that companies benefit from those appointments.

This study investigates 742 non-financial main board-listed companies for the financial year 2013, a year after the introduction of MCCG (2012). Hence the results may not apply to financial companies and other years. Future research can perhaps include all types of listed companies and execute a longitudinal study to gain a more comprehensive result and understanding on the relationship between corporate governance and corporate performance. Additionally, future research could also consider employing a different methodology such as interviews to further ascertain factors influencing corporate performance. 
1. The list was taken from Bursa Malaysia website on 18 June 2014.

\section{References}

Afrifa, G.A. and Tauringana, V. (2015), "Corporate governance and performance of UK listed small and medium enterprises”, Corporate Governance, Vol. 15 No. 5, pp. 719-733, doi: 10.1108/CG-032015-0029.

Agrawal, A. and Knoeber, C. (1996), "Firm performance and mechanisms to control agency problems between managers and shareholders", Journal of Financial and Quantitative Analysis, Vol. 31 No. 3, pp. 337-397, doi: 10.2307/2331397.

Ahmed Haji, A. (2014), "The relationship between corporate governance attributes and firm performance before and after the revised code: some Malaysian evidence", International Journal of Commerce and Management, Vol. 24 No. 2, pp. 134-151, doi: 10.1108/IJCoMA-02-2012-0009.

Ahmed Haji, A. and Mubaraq, S. (2015), "The implications of the revised code of corporate governance on firm performance A longitudinal examination of Malaysian listed companies", Journal of Accounting in Emerging Economies, Vol. 5 No. 3, pp. 350-380, doi: 10.1108/JAEE-11-2012-0048.

Al Farooque, O., Buachoom, W. and Sun, L. (2020), "Board, audit committee, ownership and financial performance - emerging trends from Thailand", Pacific Accounting Review, Vol. 32 No. 1, pp. 54-81, doi: 10.1108/PAR-10-2018-0079.

Al-Matari, E.M. (2020), "Do characteristics of the board of directors and top executives have an effect on corporate performance among the financial sector? Evidence using stock", Corporate Governance, Vol. 20 No. 1, pp. 16-43, doi: 10.1108/CG-11-2018-0358.

Alabdullah, T.T.Y. (2018), "The relationship between ownership structure and firm financial performance: evidence from Jordan”, Benchmarking: An International Journal, Vol. 25 No. 1, pp. 319-333, doi: 10.1108/BIJ-04-2016-0051.

Alipour, M. (2013), "An investigation of the association between ownership structure and corporate performance: empirical evidence from Tehran Stock Exchange (TSE)", Management Research Review, Vol. 36 No. 11, pp. 1137-1166, doi: 10.1108/MRR-08-2012-0188.

Ang, J.S. and Ding, J.K. (2006), "Government ownership and the performance of government-linked companies: the case of Singapore", Journal of Multinational Financial Management, Vol. 16 No. 1, pp. 64-88, doi: 10.1016/j.mulfin.2005.04.010.

Bhatt, R.R. and Bhattacharya, S. (2015), "Board structure and firm performance in Indian IT firms", Journal of Advances in Management Research, Vol. 12 No. 3, pp. 232-248, doi: 10.1108/JAMR-072014-0042.

Brick, I.E. and Chidambaran, N.K. (2010), "Board meetings, committee structure and firm value", Journal of Corporate Finance, Vol. 16 No. 4, pp. 533-553, doi: 10.1016/j.jcorpfin.2010.06.003.

Chen, Z., Cheung, Y.L., Stouraitis, A. and Wong, A.W.S. (2005), "Ownership concentration, firm performance and dividend policy in Hong Kong", Pacific-Basin Finance Journal, Vol. 13 No. 4, pp. 431-449, doi: 10.1016/j.pacfin.2004.12.001.

Claessens, S., Djankov, S. and Lang, L.H.P. (2000), "The separation of ownership and control in East Asian corporations", Journal of Financial Economics, Vol. 58 Nos 1-2, pp. 81-112, doi: 10.1016/ S0304-405X(00)00067-2.

Daily, C.M. and Dalton, D.R. (2004), "Boardroom myths: reconciling prescription and research guidance", Handbook of Business Strategy, Vol. 5 No. 1, pp. 15-18, doi: 10.1108/ 10775730410494044.

Darko, J., Aribi, Z.A. and Uzonwanne, G.C. (2016), "Corporate governance: the impact of director and board structure, ownership structure and corporate control on the performance of listed companies on the Ghana stock exchange”, Corporate Governance, Vol. 16 No. 2, pp. 259-277, doi: 10.1108/CG-11-2014-0133. 
AJAR 5,2

Fama, E.F. and Jensen, M.C. (1983), "Separation of ownership and control", Journal of Law and Economics, Vol. 26, pp. 301-325.

Fauzi, H. and Musallam, R.M. (2015), "Corporate ownership and company performance: a study of Malaysian listed companies", Social Responsibility Journal, Vol. 11 No. 3, pp. 439-448, doi: 10. 1108/SRJ-05-2014-0064.

FraserZhang, D.R.H. and Derashid, C. (2006), "Capital structure and political patronage: the case of Malaysia”, Journal of Banking and Finance, Vol. 30 No. 4, pp. 1291-1308, doi: 10.1016/j.jbankfin. 2005.05.008.

Gomez, E.T. and Jomo, K.S. (2002), Malaysia's Political Economy: Politics, Patronage and Profits, 2nd ed., Cambridge University Press, Cambridge.

Gujarati, D.N. (2003), Basic Econometrics, 4th ed., McGraw-Hill, West Point.

Haniffa, R.M. and Cooke, T.E. (2002), "Culture, corporate governance and disclosure in Malaysian corporations”, Abacus, Vol. 38 No. 3, pp. 317-349, doi: 10.1111/1467-6281.00112.

Haniffa, R.M. and Hudaib, M. (2006), "Corporate governance structure and performance of Malaysian listed companies”, Journal of Business Finance and Accounting, Vol. 33 Nos 7-8, pp. 1034-1062, doi: 10.1111/j.1468-5957.2006.00594.x.

Himmelberg, C.P., Hubbard, R.G. and Palia, D. (1999), "Understanding the determinants of managerial ownership and the link between ownership and performance", Journal of Financial Economics, Vol. 53 No. 3, pp. 353-384, doi: 10.1016/S0304-405X(99)00025-2.

Ho, S.S.M. and Wong, K.S. (2001), "A study of the relationship between corporate governance structures and the extent of voluntary disclosure", Journal of International Accounting, Auditing and Taxation, Vol. 10 No. 2, pp. 139-156, doi: 10.1016/S1061-9518(01)00041-6.

Hussain, M. and Hadi, A. (2019), "Corporate governance, risky business and construction industry: a divergence between Bursa and construction industry development board (CIDB) klang valley, Malaysia”, Corporate Governance, Vol. 19 No. 3, pp. 438-457, doi: 10.1108/CG-03-2018-0107.

Jackling, B. and Johl, S. (2009), "Board structure and firm performance: evidence from India's top companies”, Corporate Governance, Vol. 17 No. 4, pp. 492-509, doi: 10.1111/j.1467-8683.2009. 00760.x.

Jensen, M.C. (1993), "The modern industrial revolution, exit and the failure of internal control systems", The Journal of Finance, Vol. 48 No. 3, pp. 831-880, doi: 10.1111/j.1540-6261.1993. tb04022.x.

Jensen, M.C. and Meckling, W.H. (1976), "Theory of the firm: managerial behaviour, agency costs and ownership structure", Journal of Financial Economics, Vol. 3 No. 4, pp. 305-360, doi: 10.1016/ 0304-405X(76)90026-X.

Johnson, S. and Mitton, T. (2003), "Cronyism and capital controls: evidence from Malaysia", Journal of Financial Economics, Vol. 67 No. 2, pp. 351-382, doi: 10.1016/S0304-405X(02)00255-6.

Kao, M.F., Hodgkinson, L. and Jaafar, A. (2019), "Ownership structure, board of directors and firm performance: evidence from Taiwan”, Corporate Governance, Vol. 19 No. 1, pp. 189-216, doi: 10. 1108/CG-04-2018-0144.

Khanchei, I. (2007), "Corporate governance: measurement and determinant analysis", Managerial Auditing Journal, Vol. 22 No. 8, pp. 740-759, doi: 10.1108/02686900710819625.

La Porta, R., Lopez De Silanes, F. and Shleifer, A. (1999), "Corporate ownership around the world”, The Journal of Finance, Vol. 54 No. 2, pp. 471-517, doi: 10.1111/0022-1082.00115.

Lappalainen, J. and Niskanen, M. (2012), "Financial performance of SMEs: impact of ownership structure and board composition", Management Research Review, Vol. 35 No. 11, pp. 1088-1108, doi: $10.1108 / 01409171211276954$.

Leng, C.A. (2004), "The impact of corporate governance practices on firms' financial performance", ASEAN Economic Bulletin, Vol. 21 No. 3, pp. 308-318, available at: https://www.jstor.org/stable/ 25773828. 
Leng, C.A. and Abu Mansor, S. (2005), 'Can good corporate governance practices contribute to firms' financial performance? - evidence from Malaysian companies", International Journal of Business, Governance and Ethics, Vol. 1 No. 4, pp. 350-362, doi: 10.1504/IJBGE.2005.006717.

Lopez-Quesada, E., Camacho-Minano, M. and Idowu, S.O. (2018), "Corporate governance practices and comprehensive income”, Corporate Governance, Vol. 18 No. 3, pp. 462-477, doi: 10.1108/CG-012017-0011.

Mak, Y.T. and Kusnadi, Y. (2005), "Size really matters: further evidence on the negative relationship between board size and firm value", Pacific-Basin Finance Journal, Vol. 13 No. 3, pp. 301-318, doi: 10.1016/j.pacfin.2004.09.002.

Mardnly, Z., Mouselli, S. and Abdulraouf, R. (2018), "Corporate governance and firm performance: an empirical evidence from Syria”, International Journal of Islamic and Middle Eastern Finance and Management, Vol. 11 No. 4, pp. 591-607, doi: 10.1108/IMEFM-05-2017-0107.

MCCG (2000), Malaysian Code on Corporate Governance, Securities Commission, Kuala Lumpur, pp. 1-47.

MCCG (2007), Malaysian Code on Corporate Governance, Securities Commission, Kuala Lumpur, pp. 1-19.

MCCG (2012), Malaysian Code on Corporate Governance, Securities Commission, Kuala Lumpur, pp. 1-23.

Meng, S.C. (2009), “Are these directors truly independent?”, The Edge, The Edge Communications Sdn. Bhd., Petaling Jaya, January, p. 1.

Mishra, R.K. and Kapil, S. (2018), "Effect of board characteristics on firm value: evidence from India", South Asian Journal of Business Studies, Vol. 7 No. 1, pp. 41-72, doi: 10.1108/SAJBS-082016-0073.

Morck, R., Shleifer, A. and Vishny, R.W. (1988), "Management ownership and market valuation: an empirical analysis", Journal of Financial Economics, Vol. 20, pp. 293-315, doi: 10.1016/0304405X(88)90048-7.

Mohd Ghazali, N.A. (2010), "Ownership structure, corporate governance and corporate performance in Malaysia", International Journal of Commerce and Management, Vol. 20 No. 2, pp. 109-119, doi: 10.1108/10569211011057245.

Mohd Ghazali, N.A. (2014), "Board of directors and performance of Malaysian companies", International Journal of Managerial and Financial Accounting, Vol. 6 No. 2, pp. 117-132, doi: 10. 1504/IJMFA.2014.064517.

Mohd Ghazali, N.A. and Weetman, P. (2006), "Perpetuating traditional influences: voluntary disclosure in Malaysia following the economic crisis", Journal of International Accounting, Auditing and Taxation, Vol. 15 No. 2, pp. 226-248, doi: 10.1016/j.intaccaudtax.2006.08.001.

Nguyen, T.T.M., Evans, E. and Lu, M. (2017), "Independent directors, ownership concentration and firm performance in listed companies: evidence from Vietnam", Pacific Accounting Review, Vol. 29 No. 2, pp. 204-226, doi: 10.1108/PAR-07-2016-0070.

Ofoeda, I. (2017), "Corporate governance and non-bank financial institutions profitability", International Journal of Law and Management, Vol. 59 No. 6, pp. 854-875, doi: 10.1108/ IJLMA-05-2016-0052.

Puni, A. and Anlesinya, A. (2020), "Corporate governance mechanisms and firm performance in a developing country", International Journal of Law and Management, Vol. 62 No. 2, pp. 147-169, doi: 10.1108/IJLMA-03-2019-0076.

Rahman, R.A. and Haniffa, R.M. (2005), "The effect of role duality on corporate performance in Malaysia", Corporate Ownership and Control, Vol. 2 No. 2, pp. 40-47, doi: 10.22495/cocv2i2p4.

Shao, L. (2019), "Dynamic study of corporate governance structure and firm performance in China: evidence from 2001-2015”, Chinese Management Studies, Vol. 13 No. 2, pp. 299-317, doi: 10.1108/ CMS-08-2017-0217. 
AJAR

5,2

298
Shen, W. and Lin, C. (2009), "Firm profitability, state ownership, and top management turnover at the listed firms in China: a behavioral perspective", Corporate Governance: An International Review, Vol. 17 No. 4, pp. 443-456, doi: 10.1111/j.1467-8683.2009.00725.x.

Tabachnick, B.G. and Fidell, L.S. (2001), Using Multivariate Statistics, 2nd ed., Allyn and Bacon, Boston, MA.

Vafeas, N. (1999), "Board meeting frequency and firm performance", Journal of Financial Economics, Vol. 53 No. 1, pp. 113-142, doi: 10.1016/S0304-405X(99)00018-5.

Zeitun, R. and Tian, G.G. (2007), "Does ownership affect a firm's performance and default risk in Jordan?”, Corporate Governance, Vol. 7 No. 1, pp. 66-82, doi: 10.1108/14720700710727122.

\section{Corresponding author}

Nazli Anum Mohd Ghazali can be contacted at: nazlianum@iiium.edu.my

For instructions on how to order reprints of this article, please visit our website: www.emeraldgrouppublishing.com/licensing/reprints.htm Or contact us for further details: permissions@emeraldinsight.com 